Нона Шандроха

Гродна

\title{
Хрысціянская пропаведзь
} як актыўны рытарычны жанр маўлення

Рэлігійная тэматыка колькі дзесяткаў гадой назад з'яўлялася практычна закрытай тэмай для лінгвістычнага даследавання. Разам з тым менавіта рэлігія ва ўсе часы была галіной павышанай увагі да слова. У канцы XX-га - пачатку XXI-га стагоддзяў заўважна пашырылася прастора рэлігійнай камунікацыі і канфесійная сфера пачала актыўна ўваходзіць у грамадска-маўленчую практыку. Сярод жорстка рэгламентаваных і кананізаваных жанраў рэлігійнай камунікацыі належнае месца займае хрысціянская пропаведзь, якая у д дадзеным артыкуле разглядаецца не толькі як пэўная разнавіднасць публічнага маўлення і прамова рэлігійна-павучальнага зместу, але найперш як аратарскі тэкст і актыўны рытарычны жанр маўлення.

На думку мовазнаўцы Н. Б. Мячкоўскай, царкойная пропаведзь лічыцца фундаментальным жанрам рэлігійнай камунікацыі. 3 naчаткам пропаведзі слова пачынае жыць ў свядомасиі пэўнага згуртавання людзей. Калі слова Бога, пачутае прарокам, - гэта містычны "першаштуршок" у зараджэнні рэлігіi, то пропаведзь, у якой прарок (святар) даносіць Божае Слова людзям, - гэта "другі штуршок", і прычьмм не містычны, а иалкам назіральны. Рэлігія як містыичны камунікатыўны працэс пачынаечиа менавіта з пропаведзі вучэння людзям 1 . Насамрэч, традыцыйна адносячыся да сферы духойнага красамоўства і з'яўляючыся неад'емнай часткай хрысціянскага бо-

1 Н. Б. Мечковская, Язык и религия, Москва 1998, с. 205. 
гаслужэння, уся хрысціянская пропаведзь, як і культура, пабудавана на аратарскім майленні.

Здаўна названы спецыфічны від маўленчай камунікацыі прадугледжваў, каб жывое слова свяшчэнніка (адрасанта) тлумачыла прыхаджанам (адрасату) прачытаны з пэўнай нагоды тэкст Святога Пісання з мэтай аказання рэлігійна-матываванага ўздзеяння. Прапаведніцкае слова адметнае гарманічным спалучэннем павучальнага і дзейнага, таму і ставіць мэтай не толькі паведаміць і растлумачыць прысутнай аўдыторыі вучэнне Ісуса Хрыста, дапамагчы раскрыць вечныя ісціны, але i, галоўнае, пераканаць прыняць гэтыя ісціны. Акцэнтуем увагу на аснойных момантах рытарычнай арганізацыі хрысціянскай пропаведзі.

1) прывітанне, якое непасрэдна сігналізуе пра пачатак пропаведзі: У імя Айиа і Сьна і Святога Духа!

2) паведамленні, дзе прадугледжваецца мэта аб'явіць тэму пропаведзі і ўстанавіць кантакт з айдыторыяй: $У$ сённяшні дзень, браmbl $i$ сёстрыл, мьл разам з усёю паўнатою Святой Хрыстовай Праваслаўнай Царквь адзначаем свята Уваходу Гасподняга ў Іерусалім. Гэта свята - адно з самьх трагічных святаў усяго иаркоўнага года ; Сённяшні дзень - Дзень памяиі уссіх беларускіх святых. Гісторыля народу найбольш ярка ўвасоблена ў духоўньх вобліках, справах і творчьъх плёнах яго лепшых сыноў $i$ дачок... (113); Сёння Святая Царква ўспамінае ўсіх святых праайџоў - тых людзей, якія верай $i$ чаканнем прылшэсия Хрыста Месіі жылі ў Cтарылм Запавеце (230) і інш.

3) віншаванні 3 нагоды вялікіх царкойных святаў: Віншую вас, дарагія братьл $і$ сёстрыл, з вялікім $i$ радасньл святам - сусветнай радасию Светлага Хрыстова Уваскрасення! (47); Дарагія айцьи, браmыл $i$ сёстры, сардэчна віншую вас з вялікім, выратавальньлм $i$ радасным святам Нараджэння Госпада Бога $і$ Збавічеля нашага Iісуса Хрысты (327) і інш.

4) пажаданні і заклікі, якія гучаць пераважна ў заключнай частцы пропаведзі і гарантуюць поспех эмацыйнага ўздзеяння названага жанру на слухачоў: Хацелася б шчьра пажадаць вам такой пасхальнай радасиі, якая б ніколі у вас не змяншалася $i$ не страчвалася б. Няхай гэта пасхальная радасць умачоўвае ў нашьх сэриах $i$ веру, $i$ надзею,

2 Арцемій (Кішчанка), Пропаведзі, Мінская Духоўная Акадэмія імя св. Кірыла Тураўскага, Жыровічы [Б.и.] 2010, с. 34. Далей пры спасылцы на гэта выданне у дужках падаецца старонка. 
$i$ любоў да Бога, $i$ да ўсіх тых людзей, якія знаходзячиа побач з намі (50); Хай кожны вымяче прэч з душы сваёй калючае смецие граху, запалічь свечку веры і лампаду надзеі, сагрэе свой унутраны свет святою любоўю - $і$ ўпрыгожыциа храм душы хрысціянскай, у якім павінен нарадзічиа Сьин Божь, Гасподзь $і$ Збавічель наш! (326); У гэтую святую і таемную ноч дазвольче пажадаџь усім вам самага галоўнага i неабходнага ў нашым жыциі - свяшчэннага дару веры. Радасиі $і$ нябеснага спакою жадаю вам. Няхай уиялесніўшыся Хрыстос Збавічель умачуе нашу веру. Няхай гэта вера будзе нашай сілаю ў жыциёвых выпрабаваннях. Няхай яна будзе нашай зоркай на шляху да Бога. Няхай свята Нараджэння Хрыстова стане святам нараджэння Хрыста ў нашай душы $і$ святам нашага адраджэння ў Хрысие (328-329) і інш.

$5)$ абавязковая рытуальная канщоўка Амінь.

У тэксце пропаведзі святар свядома абірае рытарычную форму непасрэднага, адкрытага і эмацыйнага звароту да ўсіх разам і да кожнага паасобку. Прычым, форму болей звыклую, паўсядзённую і даступную для ўспрымання. Увогуле, прапаведніцкае маўленне дакладна даносіць аўтарскую думку, перадае эмацыйна-псіхалагічны стан, асабістыя адносіны святара да з'яў і падзей, якія ім узнаўляюцца. Распаўсюджанымі ў тэксце пропаведзі з'яўляюцца маўленча-дыялагічныя фігуры, якія ўжываюцца для стварэння ўрачыстых і ўзнёслых кантэкстаў з мэтай узмацнення выразнасці маўлення. Да іх мэтазгодна аднесці рытарычныя пытанні, звароты, воклічы, пытальна-адказавы ход і дубітацыю. Сутнасць фігур названай групы - стварыць сітуацыю ўмойнага дыялогу, каб прамоўца змог актыўна ўздзейнічаць на адрасата і пераканаць у сваіх поглядах. Так, у рытарычных пытаннях запыт ставіцца не $з$ мэтай атрымаць адказ ад чытача ці суразмоўцы, а каб максімальна акцэнтаваць увагу на з'яве, падзеі, факце або ўвогуле на тэме прамовы, арганізаваць аднадумства аўтара і чытача: $A$ xiбa можа быць праведным жыичё, калі ўяўленні ў нас пра яго лжывыя? (12); Хлусня! - иі не гэта і ёсць ияпер $і$ для нас тая страшная хвароба, што ставіць сучасны свет на мяжу катастрофь?! (71); і інш. Як бачна, рытарычныя пытанні не толькі ажыўляюць публічнае маўленне, надаюць яму дынамічнасць і выразнасць, але і дыялагізуюць маналагічнае маўленне. Святар сумесна з прыхаджанамі разважае і прыходзіць да адпаведнага пераканання. Побач $з$ рытарычным пытаннем у пропаведзі даволі пашыраны і рытарычны вокліч - сцвярджэнне з'яў, фактаў, яго павышанай эмацыйнай значнасці ў форме воклічу, які і стварае інтанацыйны, эмацыйны і вобразны акцэнт у тэксце: Як мьл жадаем, каб Гасподзь ставіуся да нас, так $і$ мьи павінны ставічца 
да кожнага чалавека! (151); Будзь верны Богу, і Гасподзь иябе захавае ад усіх бедаў, якія будуць у свеце! (350) і інш.

Эмацыйным зваротам да нерэальных субяседнікаў характарызуецца рытарычны зварот. Прычым форма звароту выкарыстоўваецца не столькі для таго, каб назваць адрасата, колькі для прыцягвання ӱвагі да названага адрасата з боку іншых асоб. Рытарычны адрасат нічым не абмежаваны: ім можа быць і той, хто не прысутнічае ў працэсе маўлення. Напрыклад: Госпадзі, дапамажь нам ніколі не адвярнуииа ад Цябе, як было гэта з народам ізраільскім, не здрадзіџь Табе, як зрабіу гэта Іуда, а прынячь Цябе як Збавічеля! Дапамажы нам быць адданымі Табе ва ўсе дні нашага жыция! (38); Свячічель Божы Нікалай, дапамагай усім нам годна выконвачь наша хрысціянскае прызначэнне! (351); Таму маліся заўсёды, хрысиіянская душа, каб Гасподзь прыйшоў табе на дапамогу $і$ ўмачаваў веру, каб яна была сапраўды ивёрдаю верай хрыссиіянскай! (139) і інш.

Шырокім дыяпазонам ужывання ў прапаведніцкай публіцыстыцы вызначаецца пытальна-адказавы ход - маўленчая фігура, заснаваная на тым, што святар фармулюе пытанне (пабуджае прыхаджан да роздуму) і сам адразу ж адказвае на яго. Названая фігура дастаткова папулярная у пропаведзі, дзе знешне імітуецца свабодны дыялог, які зручны для пераходу ад апісальна-маналагічнага да дыялагічнага маўлення: Чаму змірэнне набліжае да нас благадаџь Божую $і$ сілу Божую, якая змяняе наша жыциё? Таму што яно адкрывае ў нас самае лепшае, што ў нас ёсць - любоў. Бог ёсць Любоў (189); Каму Гасподзь з'яўляециа $і$ каму адкрывае Сябе? Толькі тым, хто мае адвагу Яго вызнаваць. А што гэта азначае? Гэта пэўная жыцчёвая пазіџья. I сутнасць гэтай жьичёвай пазіџыі у тылм, каб не быџь, як усе (79); Дзе тая мэта, да якой мы павіннь імкнуциа? А мэта гэтая не што іншае, як Царква Хрыстова (82); і інш. Як бачна, прамоўца постпазіцыйна пацвярджае, дае сваю ацэнку з мэтай упэўніцца у згодзе суразмоўцы або зрабіць яго аднадумцам. Заўважым, што даволі часта пытальна-адказавая форма можа ўскладняцца дубітацыяй - фігурай маўлення, якая выражае роздум або сумненне і пабудавана ў форме шэрагу пытанняй субяседніку для пастанойкі праблемы і абгрунтавання разважання. Пытанні могуць быць звернуты ці да самога сябе (прамоўцы), ці да аўдыторыі. Названая фігура робіць разважлівым тэмп маўлення, але не замаруджвае, не запавольвае яго, а, наадварот, узмацняе сэнсавае і эмацыйнае напружанне маўлення: Шлат шляхоў да збаўлення, але які з $і x$ самы лёгкі? Ці можам мы выратавациа без асаблівых намаганняў, без абмежавання свайго чела? Ці ёсць та- 
кі шлях? Так, ёсць! (146); Спытаем сёння ў саміх сябе, иі імкнемся мы пасеяць $i$ ўзгадаваць у сэрцах нашых насенне добрых намераў $i$ жаданняў? Ці ёсџь у нас, у нашай дзейнасці парасткі хрысціянскай дабрадзейнасиі? А жыциё наша на зямлі малое, час севу кароткі. Імгненнем пройдзе жыциё, скончыциа час сяўбы, апынемся перад магілай, i тады страшна будзе з'явіџиа на той свет ні з чьмм (191) і інш.

Названыя сродкі дыялагізацыі маўлення садзейнічаюць папулярнаму ўжыванню "мы”-канструкцый, што, натуральна, утварае пэўную танальнасць субяседавання: $\mathrm{Mbl}$ разам з вамі слухаем...; Mbl ведаем...; Калі мь ўважліва паглядзім на саміх сябе... і інш. Да пэўнага "актывізатара" прапаведніцкага тэксту можна аднесці і так званую павучальную танальнасць ${ }^{3}$, якая экспліцыруецца $\ddot{\mathrm{y}}$ тэксце пропаведзі праз дзеяслоўныя канструкцыі, што выражаюць ідэю павіннасці і неабходнасці: I мы павінны пачуць (падкрэслена - Н.ШІ) словы $i$ адгукнуциа на ix, таму што Гасподзь прыйшоў выратавачь, адухатварыць $і$ змянічь жыциё не толькі ўсіх, але $i$ кожнага з нас (49); Мы павінны не проста верыць (падкрэслена - Н.Ш.) у быциё Бога, а паверыць у Таго Бога, Які дзеля нас, людзей, $i$ дзеля нашага збаўлення стаў чалавекам, пацярпеў пакуты і прыняў смериь... (52); I, нарэшче, мьи ніколі не павінньи адыхходзічь ад Царквьи (падкрэслена - Н.ШІ.), страчвачь жывяю сувязь з Ёй (97); Мыл павінны помніць (падкрэслена - Н.ШІ.), што для Бога няма перашкодаў, была б толькі наша вера і наш давер да Яго! (118); Мы павінны мець вялікую пакору (падкрэслена - Н.Ш.) перад воляй Божай. Мы павінны быць гатовы прыняць тое (падкрэслена - Н.ШІ.), што Гасподзь дасць, нягледзячьи на нашы просьбы, і нічога не патрабавачь ад Яго, як гэта звычайна бызвае з намі (123); Таксама $i$ мьи павінны так паступаць (падкрэслена - Н.ШІ.), калі паўстане бура душэўная, калі парушыциа спакой сэриа намерамі грахоўнымі (138) і інш. Як бачым на праілюстраваных прыкладах, канкрэтныя ўказанні на тое, як непасрэдна трэба думаць і дзейнічаць у той ці іншай сітуацыі, ствараюць асноўны каркас павучальнай танальнасці тэксту хрысціянскай пропаведзі.

Пададзены вышэй экспрэс-аналіз хрысціянскай пропаведзі сведчыць аб тым, што яе аратарскі характар абумоўлены ўжо нават самой рытарычнай структурай і дастаткова высокай ужывальнасцю такіх экспрэсіўных сродкай маўлення, як рытарычныя пытанні, зваро-

3 Т. В. Ицкович, Православная проповедь как тuп текста: автореф. дис. ... канд. филол. наук: 10.02.01 / Уральский гос. ун-т., Екатеринбург 2007, с. 21. 
ты, воклічы, пытальна-адказавы ход, дубітацыя, эмацыйна-экспрэсіўная лексіка, "мы"-канструкцыі і павучальная танальнасць. Разгледжаная толькі ў самых агульных штрыхах названая тэма, вядома, чакае свайго далейшага плённага даследавання. Хрысціянская пропаведзь ўсё больш актыўна пашырае сферы рэлігійнай камунікацыі і мае ўсе падставы лічыцца рытарычным жанрам маўлення.

\section{S T R E S Z C E N I E}

\section{KAZANIE CHRZEŚCIJAŃSKIE JAKO AKTYWNY, RETORYCZNY GATUNEK WYPOWIEDZI}

W artykule omówiono chrześcijańskie kazanie nie tylko jako typ wypowiedzi publicznej o treści religijno-dydaktycznej, ale przede wszystkim jako tekst oratorski i aktywny retoryczny gatunek wypowiedzi. Zwrócono uwagę na środki retoryczne dialogizacji wypowiedzi w tekście kaznodziejskim.

Słowa kluczowe: kazanie chrześcijańskie, tekst oratorski, powitanie, ogłoszenie, pozdrowienie, życzenia, wezwanie, gatunek retoryczny.

\section{S U M M A R Y}

\section{CHRISTIAN SERMON AS AN ACTIVE RHETORIC GENRE}

In this article, the sermon is considered not only as a form of public speech and a text of religious and didactic content but primarily as an active oratorical and rhetorical speech genre. A major focus has been placed on rhetorical means of speech dialogization in the text of a sermon.

Key words: Christian sermon, oratorical speech, greeting, announcement, salutation, wishes, summons, rhetoric genre. 